d. COLUMBIA | SIPA

Center on Global Economic Governance

CGEG-CDEP WORKING PAPER SERIES

CGEG-CDEP WP No. 32

From Global Savings Glut to Financing Infrastructure

Rabah Arezki, Patrick Bolton, Sanjay Peters, Frédéric Samama and Joseph Stiglitz

November 2016

曾 COLUMBIA |SIPA

Center for Development Economics and Policy 


\title{
From Global Savings Glut to Financing Infrastructure ${ }^{1}$
}

\section{Rabah Arezki, Patrick Bolton, Sanjay Peters, Frédéric Samama and Joseph Stiglitz}

International Monetary Fund; Columbia University; Copenhagen Business School; Amundi Asset Management; Columbia University

\begin{abstract}
This paper proposes an institutional solution that can help unlock the flow of low yielding longterm savings towards high-return infrastructure investments. The solution is to transform public-private partnerships in infrastructure and the classic model of multilateral development banks. Instead of thinking of public-private partnerships as bilateral contracts between a private concession operator and a government agency, we argue that they should be conceived as partnerships that also involve a development bank and long-term institutional investors as partners. We propose a new model for development banks, which is to transform themselves into originate-and-distribute banks for PPP infrastructure projects. This way they can conserve their valuable capital and leverage their expertise and capabilities by making them available to longterm institutional investors.
\end{abstract}

Keywords: Infrastructure, Public Private Partnership, Long-term Investors, Savings, and Investment Policy.

JEL Classification: H49, H54, G30, G38

\section{INTRODUCTION}

Several years after the great recession the global economy is in an appalling predicament. The needs and benefits of infrastructure investment have never been greater. At the same time accumulated global savings have never been higher. They are now so high that we have a global "savings glut", with a larger and larger

\footnotetext{
${ }^{1}$ We gratefully acknowledge the support of the Rockefeller Foundation, who hosted a meeting in Bellagio on sustainable investment in infrastructure in May 2014 that provided invaluable background for this paper. We are also grateful to the Editor, Refet S. Gürkaynak, and three anonymous referees for their helpful comments. We also thank Bertrand Badré, Olivier Blanchard, Erik Berglof, Lorenzo Bernasconi, Alex Chirmiciu, Hubert Frédéric, Thierry Déau, Roger Guesnerie, Huang Haizhou, Christopher Knowles, Jin Liqun, Prakash Loungani, Maury Obstfeld, Amadou Sy, Julien Touati, Tunç Uyanik, Waide Warner, David Wood and the Bellagio workshop participants for many helpful comments. Finally, we are grateful to Timothée Jaulin and Vanessa Diaz Montelongo for excellent research assistance. The views expressed in this paper are those of the authors and do not necessarily reflect the position of the International Monetary Fund or the Crédit Agricole Group.
} 
fraction of government bonds trading at negative yields. We also appear to be facing a "secular stagnation", with very low forecasted productivity growth. Yet, all these problems will be solved if we find a way of channeling the trillions of dollars in savings of long-term institutional investors that are currently allocated to low-yielding, fixed-income, assets towards infrastructure investments. These investments are known to produce some of the highest gains in productivity and they typically generate very high social rates of return.

This article identifies the main institutional obstacles that prevent the flow of savings towards infrastructure investment and proposes one key institutional fix to unlock the current savings glut and reverse the recent trend of secular stagnation. The solution is to reshape public-private partnerships (PPPs) in infrastructure as well as the classic model of multilateral development banks. Traditionally, PPPs have been conceived as bilateral contracts between a private concession operator and a government agency. And the mandate of development banks has been to offer financing to projects that could not attract private funding but had a high development impact. The new model we propose is to reframe PPPs as partnerships that involve three, or even four partners, with the new partners being a development bank and long-term institutional investors. And the new model for development banks is to transform them into originate-and-distribute banks for PPP infrastructure projects.

Apart from the major efforts in infrastructure development in China and a few other Asian countries, infrastructure development in most parts of the world has been seriously lagging over the past three decades. The initial hopes that the privatization wave of the 1980s would fuel a private-sector funded greenfield infrastructure investment boom have fallen well short of expectations. (see Estache and Fay, 2007 and Iossa and Martimort, 2012). Yet, the economic motivations behind the privatization push were solid. The experience with public sector infrastructure up to the 1980s in low-income countries and advanced economies was one of poor governance, large cost overruns, poor maintenance, and corruption (see Vickers and Yarrow, 1991). Too many infrastructure projects turned out to be white elephants. Moreover, the early evidence of privatization was encouraging: it resulted in greater efficiency, better maintenance and new sources of funding with the development of public private partnerships (PPPs). In all a total of over 2700 PPP projects were initiated in developing countries between 1990 and 2003 (see Hammami, Ruhashyankiko, and Yehoue, 2006). However, the most recent evidence clearly points to a relative slowdown in infrastructure development and a leveling of the flow of new PPPs in many parts of the world (see Figures 1 and 8).

Meanwhile aging infrastructure facilities deteriorate, population continues to grow, and urbanization trends carry on, so that growing infrastructure needs remain unfulfilled. The plain reality is that the global privatization experiment of the past three decades has held back the supply of new large-scale infrastructure projects in many parts of the world. Moreover, private sector funding of infrastructure will not be forthcoming in sufficient quantity under the current PPP models to meet the rising global infrastructure demand. Indeed, the current funding gap is estimated to be around \$3.3 trillion per year until 2030 (see McKinsey and Company, 2016). ${ }^{2}$ In the wake of the global financial crisis of 2007-2009 and the growing urgency of climate change mitigation, the world is at a similar new crossroad as thirty years earlier, when the Washington Consensus (Williamson, 1989) emerged as a possible new template for development following the collapse of the central planning development model of previous decades. As then, institutional innovations must be envisioned that can unlock the flow of capital towards infrastructure investment.

\footnotetext{
2 Other studies by the OECD (2012), the World Bank, the International Finance Corporation (IFC), and World Economic Forum (2013) have estimated similar aggregate infrastructure expenditure needs.
} 
Although the challenges are daunting, there are new opportunities for infrastructure development, as the size of the savings of long-term investors (Pension Funds, Insurance Companies, Sovereign Wealth Funds) has never been higher-it is currently estimated to exceed $\$ 100$ trillion worldwide (CityUK, 2013). Moreover, the bulk of these savings is invested in lower and lower yielding fixed income assets (Çelik, S. and M. Isaksson, 2013). Long-term investors are searching harder than ever for relatively safe long-term assets that offer a better return than government bonds. These investors would be better placed investing in longer term global infrastructure assets, where they are likely to face less competition from more short-term oriented investors, and where remarkably there is also a huge demand for funding. At a time when the world recovery from the financial crisis is still timid and public debt levels remain elevated, the provision of private-sector financing to help replace aging infrastructures in advanced economies and build brand new ones in emerging markets could significantly contribute to reignite economic growth and accelerate the necessary transition to renewable energy.

However, to be able to exploit these funding opportunities, important institutional bottlenecks relating to financing and origination of infrastructure projects must be removed. In this paper we argue that the institutional innovations of some development banks around infrastructure investment platforms are a promising way forward to circumvent these bottlenecks. Our proposition is that a reconfiguration of the multilateral development bank model around an originate-and-distribute model of PPP infrastructure investments is the key link between the global macroeconomic opportunities and the micro challenges in developing infrastructure.

There is accumulating evidence that the social rate of return from infrastructure investments amply justifies these investments. For example, Fernald (1999) has found that transport infrastructure-roads—substantially increases the productivity of industries that make heavy use of road transport, and Donaldson (2016) and Donaldson and Hornbeck (2016) have found substantial social and economic benefits from the creation or expansion of nationwide rail transport networks. There is, of course, the occasional "bridge to nowhere" to be found in every country, but for many observers it is stating the obvious that electrification, sanitation, and transport infrastructure is a sine qua non for development. Yet, the risk-adjusted rate of return for investors appears to be so low that far too many valuable infrastructure facilities are not provided.

The matching of demand and supply of funds for infrastructure is hindered by both market and government failures, some of which are well understood and others somewhat less so: i) the public good nature of infrastructure projects, with non-excludability and non-rivalry in consumption; ii) the market power of the operator of the infrastructure facilities, and iii) the externalities (positive and negative) including through trade, growth and network spillovers associated with infrastructure investments. Considering that infrastructure projects involve the participation of many agents (construction companies, operators, insurers, government, owners, citizens), a complex chain of tasks (building, maintenance, service delivery), and, inevitably, multiple informational asymmetries regarding quality, costs of service, and ultimate benefits, it is not surprising that major obstacles often lie on their way. Informational asymmetries, in particular, lead to market failures that call for a delicate balancing of public and private interests to ensure incentive compatibility and appropriate risk sharing at the various stages of the infrastructure project, as a large economics literature on PPPs has emphasized. For instance, a central insight of the economics literature on PPPs is that it is generally incentive-efficient to bundle construction and service-provision together with a single private operator. 
Multilateral (and regional) development banks (MDBs) play a fundamental role in reducing both market and government failures. As we shall argue, MDBs play a critical role in helping governments identify and structure infrastructure projects. Given their international governance structure they also are ideally placed to help mitigate political risk. The impact studies they undertake and the strict due diligence standards they impose in the origination of new infrastructure projects are the best guarantees of the sustainability of these projects. In short, MDBs play a critical "gate keeping” role. There is only one problem: MDBs have very limited funds available for infrastructure investment (see Figure 2). This is why, the solution is for MDBs to fundamentally transform their model into an originate-and-distribute model of PPP infrastructure projects that maximize value capture. This way they can conserve their scarce capital, and leverage their gate-keeping capabilities to give access to the vast pools of long-term institutional savings to PPP infrastructure projects.

The remainder of the paper is organized as follows. Section II provides the state of play of long-term investing in infrastructure. Section III offers a critical review of the experience and the literature on PPPs. Section IV discusses the advent of infrastructure investment platforms. Section V provides concluding remarks and observations.

\section{STATE OF PLAY}

This section advances key stylized facts about the current size of savings of long term investors, their asset allocation, and the global demand for infrastructure investment.

\subsection{Investment Patterns of Long-Terms Investors}

Institutional investors such as pension funds, insurance companies and mutual funds, and other investors such as sovereign wealth funds hold around \$100 trillion in assets under management. In 2013 CityUK estimated that pension funds, insurance companies, and mutual funds respectively held \$33.9, \$26.5 and \$26.1 trillion in assets under management (see Figure 3). In addition, sovereign wealth funds and central banks have accumulated savings approaching \$15 trillion. One gets a clearer grasp of the enormous size of this global wealth by, for example, comparing it to US nominal GDP ( \$18 trillion in 2015:Q3), or to the IMF's new arrangements to borrow ( $\$ 0.576$ trillion in 2013), or even to the total market capitalization of US listed companies (\$18.7 trillion in 2012).

According to a recent OECD report (Çelik, S. and M. Isaksson, 2013), out of $\$ 85$ trillion held by all institutional investors covered in the report, 38\% (\$32 trillion) was held in the form of publicly traded equity, with the remainder being held mainly in fixed-income securities. Traditional institutions such as pension funds and insurance companies, held \$28 trillion (38\%) in publicly traded equity, and alternative institutions, while mainly sovereign wealth funds, private equity and hedge funds, held $\$ 4.6$ trillion (40\%) in publicly traded equity. The report however warns that investment allocations for each category of institutional investors are complex to pin down, largely due to cross-investments among institutional investors, increased complexity in equity market structure, and an increase in outsourcing of ownership and asset management functions. That being said, the main lesson from these studies is that a large fraction of traditional and non-traditional investors appear to be investing primarily in government bonds and other fixed income securities.

There are however important differences across regions and individual investors, and it is encouraging to note that the targeted shares of investments in infrastructure are growing across the board, reflecting the growing realization among long-term investors that infrastructure assets are a natural habitat for their investments (see 
Figures 4 and 5). Long-term investors are indeed well placed to invest in more long-term global infrastructure assets. They match their long-term horizon, there is less competition for these assets from other investors, and there is a huge global demand for funding of these assets.

Most infrastructure investments generate cash flows only after many years and are associated with high risks during the construction phase. Financing in the form of syndicated bank loans has been an important traditional source of funds for such risky long-term projects, but the financial crisis of 2007-09, the tighter bank regulations under Basel III that have followed, and the flatter yield-curve environment, have pushed banks to significantly retrench from this risky and less profitable asset class. Nowadays, banks tend to limit loan maturity to five or eight years, while infrastructure project typically require amortization of debt over 15 to 20 years. This implies that refinancing is necessary after the initial loan period, exposing borrowers to additional refinancing risk. In turn, the lesser role of banks in long-term investment has paved the way for a greater role of long-term investors such as pension funds, insurance companies, and sovereign wealth funds. Insurance companies, in particular, have expressed strong interest in matching their long term liabilities with such long term assets. This is evidenced for example in industry surveys (see LP Perspective, 2014 and Preqin, 2016). A few statistics from these surveys are in order: i) 38 percent of investors surveyed by Preqin feel lack of deal flow as an impediment to their investment in infrastructure; ii) $48 \%$ of surveyed investors expect to invest more capital in infrastructure over 2016 than in 2015. This context explains why the G20, the group of 20 major economies, has recently endorsed high level principles intended to help governments facilitate and promote long-term investment by institutional investors including in infrastructure.

The unique nature of infrastructure projects also makes them particularly illiquid investments. The global financial crisis and the subsequent multiple episodes of excess volatility in supposedly very liquid markets have also exposed the fact that the liquidity of a whole asset class can suddenly and dramatically evaporate. This new reality, if anything, strengthens the relative value of illiquid asset classes that offer an illiquidity premium, such as infrastructure investments ${ }^{3}$. Interestingly, in the current low-yield environment, harvesting this illiquidity premium has become increasingly important for many long-term investors. ${ }^{4}$

\subsection{Infrastructure financing needs}

Against this backdrop of a largely untapped pool of global savings, estimates suggest that the world needs to increase its investment in infrastructure by nearly 60 percent until 2030 (see McKinsey Global Institute, 2013). To attain those aggregate needs, investment in infrastructure will have to increase from an accumulated total of $\$ 36$ trillion over the past 18 years to $\$ 57$ trillion over the next 18 years. Figure 6 provides several estimates, using different approaches, all pointing to massive global infrastructure needs. These estimates can be seen as somewhat conservative considering that they correspond to a scenario where current levels of infrastructure capacity and service relative to GDP are maintained under projected economic growth.

There is a huge infrastructure investment gap in a large number of countries. The average infrastructure investment gap amounts to between $\$ 1$ to 1.5 trillion per year (see Figure 7). Infrastructure investment needs

\footnotetext{
${ }^{3}$ A recent report by Allianz (2015) provides some evidence of the economic significance of such premium in the case of infrastructure debt using a basket of known securities with similar ratings and duration. Figure 1 in the above mentioned report highlights listed Private Finance Initiative (PFI) bonds versus a listed A-rated utility and versus the 10-year swap rate. It indicates that over a 5-year period investors would have received a premium of c.100bps for purchasing an A-rated utility and a spread of $150-200$ bps for private PFI placements.

${ }^{4}$ Investing in infrastructure is different from investing in Treasuries. The latter is a financial asset that exposes investors to aggregate risk. Instead, investments in infrastructure exposes investors to more idiosyncratic risk tied to a specific project. Existing evidence suggests that the risk-return profile of infrastructure investments appears to be quite different from other long-term assets such as equities and treasuries (e.g. Blackrock 2015, Morgan Stanley 2007). Average returns on infrastructure assets are somewhat higher than for bonds and equities. The volatility of returns to infrastructure investments is also higher than for bonds but smaller than for equities.
} 
range from a low $3 \%$ of GDP in advanced economies to $9 \%$ of GDP in emerging economies, and more than $15 \%$ of GDP in some low income economies (see World Economic Forum, 2010, and 2012). Infrastructure investment needs are mostly earmarked for upgrading depreciating brownfield infrastructure projects in the EU and in the US and for greenfield investments in low-income and emerging markets.

Available estimates for Europe indicate that infrastructure investment needs up to 2020 are within the range of €1.5-2 trillion, or an annual amount of €150-200 billion on average (see European Commission, 2007). Within the infrastructure domain, energy is identified as the largest sector for investment, ahead of transport and communication. More recently, the European Commission (2013) estimated that for the EU, "overall investment needs for transport, energy and telecom infrastructure networks, amount to $€ 1$ trillion for the period up to 2020.” Those estimates cover a limited set of sectors and should thus be treated as a lower bound. It is worth noting that the European Investment Bank (EIB) has an annual volume of financing in the €50-70 billion range, and the Junker investment plan is around €315 billion over three years, thus significantly falling short of estimated infrastructure investment needs.

In the US infrastructure needs are estimated to be over $\$ 2.75$ trillion by 2020 to be able to adequately serve the growing U.S. population and increased economic activity, as well as maintain or rebuild infrastructure in need of repair, or replacement (see American Society of Civil Engineers, ASCE). However, only \$6 billion of Recovery Act funding was available to spend on infrastructure in the Fiscal Year of 2012. Overwhelmingly the most pressing need for infrastructure is in surface transportation, including highways, bridges, railroads, and other transit systems.

Overall, however, the future growth in the demand for infrastructure will come increasingly from emerging economies. Over the past 18 years, more than $70 \%$ of global infrastructure investment originated in advanced economies (see McKinsey Global Institute, 2013). But over the next 18 years emerging economies are likely to account for 40 to 50 percent of all infrastructure spending. Around $70 \%$ of the current pipeline available to equity investors consists of green-field projects, which are viewed as much riskier than brown-field investments, particularly in emerging economies ${ }^{5}$. Even though a growing number of investors are rethinking their investment strategies in light of these developments, they will continue to demand higher returns and will be more selective considering the riskier nature of green-field investments.

Available estimates suggest that if institutional investors (excluding SWFs) were to increase their allocations for infrastructure financing to their target levels, it would result in an additional \$2.5 trillion in infrastructure investment capital through 2030 (e.g. McKinsey Global Institute, 2013). This study however highlights that while "This is a sizeable amount, [it is] still only a fraction of global infrastructure investment needs. We therefore need to look elsewhere for a complete solution...” As mentioned earlier, assets under management by long-term investors have reached $\$ 85$ trillion. Even if a small portion of assets under management of longterm investors were to be earmarked for infrastructure development on a global scale, the impact on the global economy, as well as commercial returns could be bigger than any other source of large-scale private investments.

${ }^{5}$ To the extent that greenfield investments involve a higher time to maturity and greater regulatory and enforcement risks they are fundamentally riskier for investors than proven brownfield investments that are already in operation. 


\section{INVESTING IN INFRASTRUCTURE THROUGH PUBLIC-PRIVATE PARTNERSHIPS}

In this section we highlight how the economics literature on PPPs has almost entirely been framed around incentive issues that were prominent at the time when the first privatizations were initiated, and how this literature is mostly silent on the origination, financing, and contract enforcement issues that have since hindered and plagued PPPs in many countries. We also discuss the critical law, finance, and economics aspects of PPP origination, financing and enforcement.

\subsection{THE MICROECONOMICS OF PPPS: THE GAP BETWEEN THEORY AND REALITY}

Most of the economics literature on PPPs is cast in a dynamic bilateral Principal-Agent framework (see Iossa and Martimort, 2015 for an overview) ${ }^{6}$. The Principal is the government and the Agent is the infrastructure provider. The early contributions to this literature are motivated by the privatization experience in the UK in the 1980s and the subsequent proliferation of infrastructure service provision under PPP arrangements. The record of publicly provided infrastructure services in the UK prior to the privatization wave of the 1980s was rife with inefficiencies and underinvestment in maintenance and technological upgrades. In light of this evidence, economists not surprisingly, pointed to the lack of incentives for the public infrastructure service providers to minimize cost, increase quality, and maintain the infrastructure facility. A basic observation of incentive theory (Mirrlees 1999, Holmstrom 1979) is that the agent providing a service will have stronger incentives to perform if her compensation is tied to performance. Given that public infrastructure service providers were not compensated based on performance it was not surprising that public infrastructure service provision, whether in transport, energy, water, health, education or telecommunication was deficient.

A major advantage of privatization, and of the private provision of infrastructure services, is that the provider is compensated based on performance, as measured by profit. However, a major "inconvenience", well recognized by the early proponents of privatization, is that maximization of profit by a monopoly infrastructure service provider exploiting its market pricing power is generally not a desirable social objective. If private provision of infrastructure services can deliver desirable incentives for cost and quality performance, it also introduces undesirable monopoly distortions. Therefore, private provision of infrastructure services has to be accompanied at a minimum by rate and standards regulation, setting up a first unavoidable long-term link between the private service provider and the public regulator.

But the PPP economics literature is more specific than that. First, as Donahue (1989) has noted, the benefits of privatization are highest when private providers are also subjected to competition. When horizontal competition is not feasible because the service provider is a natural monopoly, some discipline may be introduced through vertical competition and by periodically organizing an auction for the license to provide the service. Accordingly, the UK and many other countries have introduced fixed term concession contracts that are up for competitive bidding or contract renegotiation when the private service-provision contract expires.

An important policy question is then how broad a scope and how long a term to specify in the concession contract. A central insight of the economics literature on PPPs regarding this question is that it is generally incentive-efficient to structure the concession contract by bundling construction and service-provision together with a single private operator. In practice PPPs can take several different forms: there are PPPs that

\footnotetext{
6 For a more complete list of theoretical and empirical papers on PPPs and infrastructure finance we refer the reader to: http://www.people.hbs.edu/besty/proj_nportal/articles.htm
} 
combine building, owning and operating (BOO), building, owning and transferring (BOT), building, rehabilitating, owning and transferring (BROT), rehabilitate, operate and transfer (ROT), and build, lease, own (BLO). According to Hammami, Ruhashyankiko, and Yehoue (2006), from 1990 to 2003 a total of 690 BOO, 317 BOT, 234 BROT, 108 ROT, and five BLO PPPs have been initiated. A striking result in the economics literature on PPPs is that whenever there are positive spillovers between construction and operation of an infrastructure facility it is optimal to design the PPP in the form of a BOO or BLO (see Hart, 2003, Bennett and Iossa, 2006, Martimort and Pouyet, 2008, and Iossa and Martimort, 2012 and 2015). In simple and general terms the reason why bundling is efficient is that by assigning construction and operation to the same provider, the latter has strong incentives to construct the facility so as to minimize future operating costs. $^{7}$

One drawback of structuring the PPP by bundling construction and operation, however, is that this generally involves a very long-term contract, lasting over 25 to 40 years. Moreover, under such a contract the operator faces significant risk, both during the construction phase and in the operating phase ${ }^{8}$. It is generally not efficient to expose the operator to the entire risk of the project. Again, a central lesson from agency theory (Mirrlees 1999, Holmstrom 1979) is that the optimal contract between a principal and an agent involves trading off risk-sharing and incentives. To the extent that the government is better able to absorb risk it makes sense to provide some insurance to the PPP operator, even if this comes at the expense of incentives to deliver services.

How much insurance should be offered, and what types of risk should be insured is not clear from the existing economics literature on PPPs. With the exception of a few studies (in particular Engel, Fisher and Galetovic, 2008) this topic has not been studied systematically. The main argument in the economics literature against any form of insurance is that investors in PPPs are diversified investors and as such are best able to hold the risk, provided of course that it is properly priced. The argument in favor of insurance is that the government has a greater ability to raise funds through taxation (see Holmstrom and Tirole, 1996) and therefore should take on as much as of the funding cost as is compatible with maintaining incentives for service provision by the PPP operator. Neither of these arguments is fully compelling nor is it always relevant to the constraints faced on the ground by the contracting parties in specific PPPs. It is striking how little attention the economics literature has devoted to the fundamental question of how to structure financing of investments under PPPs, how much should come from private sources and in what form and how much should come from public sources. An equally striking observation is that almost all the economics literature on PPPs frames the contract as a bilateral contract between a private provider and a government agency. One important exception is Dewatripont and Legros, 2005, who emphasize the important role a third party can play as a monitor to improve the efficiency of contract enforcement. In most developing countries the obvious third party is a multilateral development bank, which can play not only a key monitoring role of both the service provider and the government agency, but also a fundamental role in structuring financing efficiently and providing optimal insurance or guarantees to private investors in PPPs.

\footnotetext{
${ }^{7}$ A survey by Standard and Poor's (2007) suggests that the successful delivery of PPPs remains dependent on a number of critical prerequisites. The survey indicates that, absent these prerequisites, the construction-phase performance differential between PPPs and conventional procurement methods can narrow considerably.

${ }^{8}$ During the operating phase some PPP concession-holders may be subject to significant volume risk such as toll road operators. On the other hand, hospitals, prisons, and other such PPP operations are less subject to such demand risk during the operating phase.
} 


\subsection{Origination, Financing and Enforcement: The new economics and finance of PPPs}

As little as the economics literature has explored the issue of financing of PPPs, the most important concern of private operators and investors in practice is how to structure financing and minimize the cost of capital of PPP projects. Structuring financing of PPPs is not just a technical question; it is what supports the delicate balance between the interests and comparative advantages of the different partners in the PPP. It is not just a question of optimally allocating the different risks involved in an infrastructure project, as illustrated in Figure 10 , but also a question of setting up the right governance structure to ensure the sustainability of the project. Given the public goods nature of most PPP projects a fundamental difficulty is to find a way to internalize the positive externalities produced by the project without excessively excluding all the potential beneficiaries of the project.

This is, of course, not a new problem; what is new is the institutional context that evolves over time and technological advances. Before we discuss the new institutional context and how it shapes new approaches to the financing of PPPs it is worth mentioning a particularly instructive old model of PPPs from the MiddleAges in Europe and to contrast it with a successful modern equivalent:

"The Bridges were always the weakest links in the road network and the most difficult for occasional labour to maintain. In the course of the twelfth century local efforts began to be supplanted by a more powerful organization of resources, often of a charitable nature.” [pp 176] "It was an extremely expensive enterprise to maintain...It was normal for a toll to be levied from those using such a bridge, and sometimes as at the Pont St Esprit, from those using the river under it, to help pay for its upkeep and repair. However, tolls by themselves were not adequate to maintain a bridge. Those who planned to build one did not simply have to look for enough funds to build it in the first place, but for an adequate permanent endowment in land. The first years' rents from the bridge's lands paid for the initial building. The fact that the Pont St Esprit and its associated works took forty years to complete was not because medieval masons could not work any faster, but because it needed forty years' income to pay them. The endowment was then intended to pay for the maintenance of the fabric, of the brotherhood and of their chapel. " [From "Power and Profit: The Merchant in Medieval Europe” (2002), Peter Spufford, Thames \& Hudson, New York pp 177-178.]

A modern equivalent of the medieval "bridge financing" model is the striking example of "value capture" implemented by Hong Kong's mass transit rail corporation (MTR), a private operator with a majority stake held by the Hong Kong government. Just as medieval bridge operators had endowments of land to establish a sustainable revenue source the MTR owns properties in Hong Kong whose value appreciates as a result of the extension of the transit network (see Cervero and Murakami, 2009). As a result MTR is hugely profitable unlike most mass transit systems in the world even though ticket prices are relatively low. In 2013, for example, MTR realized an operating profit of HK\$ 16.3 billion (or \$2.10 billion) of which revenues from property development, rental \& management, and station commercial businesses represented over $50 \%$ of the profit (www.mtr.com.hk). This example illustrates how a well-designed PPP can better exploit the comparative advantages of the different partners in capturing revenue to finance infrastructure construction and operation. In MTR's case it was better placed as a private operator to combine property development with transit extension than the Hong Kong government.

A well-known problem that all too many heavily-indebted poor countries (HIPC) have faced is that their public finances are just too stretched to be able to support large infrastructure investments that are nevertheless sorely needed. Often the only way for these countries to be able to build an infrastructure facility is to rely on 
private financing through a PPP. It is most likely the reason why Hammami, Ruhashyankiko, and Yehoue (2006) have found that PPPs are most prevalent in HIPC. In these countries what drives the way the financing of the PPP is structured is basically a very tight government financial constraint. The private funding of an infrastructure project generally comes against a concession contract which assigns future toll revenues to the provider. But this is only the beginning of the PPP financial-structure problem. Two other major issues are: First, how senior the claims of the private investors should be: should private investors be senior secured lenders, subordinated bond-holders or common equity holders? If they are debt-holders, to what extent should this debt be guaranteed and by whom? Second, what are the control rights of private investors and what are their protections against the hold-up risk by host governments? ${ }^{9}$

To be sure, the implementation of PPP projects and the enforcement of PPP contracts can be fraught with conflicts. When another administration than the one that has originated a PPP project comes to power it often seeks to change the terms of the contract. Similarly, private concession operators have been seen to strategically default and abandon the project before construction is completed, leaving the local government with a white elephant. To minimize the costs of such contractual disputes it is important to not only structure the PPP contract so that it is ex post efficient and incentive compatible in as many states of the world as possible, but also to build into the contract effective dispute resolution procedures and, of course, to be able to depend on credible and speedy contract enforcement institutions.

In many countries such enforcement institutions are, alas, not available. One country that has had a particularly bad experience with PPPs because of its weak contractual enforcement institutions is India. According to a National Institution for Transforming India (NITI Aayog) 2015 report: "in a large number of cases, the project authorities do not discharge their contractual obligations in a timely manner which imposes additional costs on private sector participants. There is also lack of enforcement of the contractual obligations to be discharged by the Concessionaires." Moreover, "Infrastructure projects are fraught with disputes that cause inordinate delays due to slow resolution processes. Arbitration awards are almost invariably appealed against, resulting in long drawn out disputes that often last 3 to 10 years. As per available data ... disputes involving 870 cases are pending for resolution in the Road sector alone.” [NITI Aayog, NITI BRIEF \# 5, 2015, paragraphs 4.2.1 and 4.3.1, page 10]. Importantly however, when a country cannot effectively rely on its own legal system for the enforcement of PPP contracts it is possible for that country to fall back on international commercial arbitration, a tried-and-tested enforcement mechanism generally preferred by international investors (see World Bank Group, 2016).

The reality of infrastructure assets as an investment class is that most investors are only comfortable holding debt instruments, preferably guaranteed, in relatively safe infrastructure assets. ${ }^{10}$ This generally means that private infrastructure investors crowd into the relatively safe brownfield infrastructure-asset class (that is, projects that are already built and operating), in which yields are no longer that attractive. Far fewer investors venture into greenfield infrastructure-projects (that is, projects that are still under development), which expose them to construction, regulatory, and demand risk and involve much longer payback periods. For routine transport and energy infrastructure the construction risk is limited, but demand and regulatory risks may not be. For more unusual infrastructure investments, such as nuclear reactors, long tunnels, or major urban redevelopment projects construction risk is much more of a concern (see Box A).

\footnotetext{
${ }^{9}$ Toll revenues in developing countries are not well accepted by users, which reinforces the risk of hold-up and expropriation by the Government. In addition, toll revenues are subject to currency risk and the lack of long-term currency hedging mechanisms is a major concern for investors.

${ }^{10}$ Guarantees are rarely available and therefore seldom sought by investors (non-recourse debt remains the norm).
} 
Another consideration in the greenfield space is that most private investors only want to hold senior, secured, and if possible, guaranteed debt. Far fewer private investors venture into holdings of common equity stakes in greenfield projects because the perception of high risks, especially for investors with limited expertise in infrastructure project finance, who are most exposed to adverse selection. One notable example of a long-term investor taking equity positions in greenfield projects is the private equity firm Meridiam (http://www.meridiam.com). Remarkably, Meridiam imposes on its long-term limited partners lock-up periods of up to 20 or 25 years, more than double the typical length for a lock-up period in private equity funds. Also noteworthy is the fact that on a risk adjusted basis the returns offered by Meridiam are actually higher than the average return for brownfield investments. Meridiam typically engages in greenfield projects that have delivered double digit returns for their investors, while a pure brownfield long-term investments yielded only single digit returns. The reason behind the superior performance of Meridiam has to do, essentially, with the different business model it has adopted from the typical leveraged buy-out model in the private equity industry. Under the dominant business model in the industry most of the attention is devoted to privatization of existing infrastructure assets, instead of the origination of long-term investments in infrastructure projects. ${ }^{11}$

${ }^{11}$ To sustain its rather uncommon business model, Meridiam has invested time and resources in building an in-house multi-disciplinary team with public sector, industrial, and finance expertise. 


\section{Box A. Hinkley nuclear power plant project}

A specific, cutting-edge, example of one of the largest PPP projects ever to be envisaged, currently in the final pre-construction stage in the UK, the Hinkley Point C nuclear power EPR plants project involving the French electric utility company EDF as the private provider, a strategic partnership with China's General Power Corporation (GPC), and the UK government. ${ }^{1}$

Early consultations on the project began in October 2008 and the project is now reaching the point when construction is about to begin ${ }^{1}$. Currently, the estimated time for construction of the new EPR plant is eight years, the expected operational lifetime is sixty years, and the total capital commitment for the two reactors is expected to be around $€ 43$ billion $^{1}$.

EDF and GPC will respectively own $66.6 \%$ and $33.5 \%$ of the capital, and the UK government will provide a $£ 20$ billion loan guarantee ${ }^{1}$. Under this structure most of the construction risk is taken on by the equity owners in the PPP, and credit risk is transferred to the UK government, who is a stronger counterparty than any private default protection seller. Moreover, a particularly innovative feature of the PPP is the so-called contract for difference provision that locks in and front-loads the future prices for the Hinkley Point $\mathrm{C}$ electricity sold by EDF to the national grid. This provision, in effect, allows the private provider and the UK Government to share operating risk, and thus lower the cost of financing of the project ${ }^{1}$.

It is worth mentioning that the guarantee fee has been significantly raised by the European Commission in order to "reduce the subsidy" by the UK Government, although the subsidy had been authorized by the Commission on the grounds that the "UK authorities demonstrated that the support would address a genuine market failure". The impact of the project on EDF's balance sheet and risk profile is so large that EDF has decided for risk management purposes to increase its liquidity holdings by selling $€ 10$ billion of assets over the next five years ${ }^{1}$.

This example is remarkable not just for the sophistication of its financial structure and risk allocation, but also for its sheer size and the particularly long-term commitments that may be involved in infrastructure projects: more than seven years from the first consultations to the beginning of construction, eight years of construction, and sixty years of operating income. Such an investment asset is obviously only well suited for long-term investors, which besides the operating companies include pension funds, insurance and reinsurance companies, and sovereign wealth funds. The example is also noteworthy for its reliance on guarantees to lower the cost of debt financing. The UK Government is, of course, in a position of being able to extend such a guarantee, and thus to significantly lower the cost of capital for such projects. A simple back-of-the-envelope calculation gives the following ball-park number: assuming that the required interest payment on a thirty year AAA bond is 3\%, and the required interest payment of a thirty year bond without the guarantee is $5 \%$, the yearly interest savings to service the AAA bond versus the non-guaranteed bond for a total issue of 17 billion pounds is approximately $(850-510)=340$ million pounds. It should be noted, however, that extending a guarantee is not costless, and the present value costs of such government guarantees is generally underestimated, as Lucas (2014) has shown, since these guarantees are typically not priced under private sector, fair-value, accounting rules, which take into account compensation for risk and therefore yield cost estimates that are significantly higher. Obviously, proper risk management should identify the limits beyond which governments or MDBs can no longer efficiently extend guarantees. 


\section{MULTILATERAL DEVELOPMENT BANKS AND INFRASTRUCTURE PLATFORMS}

As Dewatripont and Legros, 2005, have argued, monitoring by a third party generally improves the efficiency of PPPs. We maintain that multilateral development banks (MDBs) are evidently the best placed third parties to play that role for several reasons. First, in most countries MDBs are obligatory entities with which government sponsors of infrastructure projects must contend. They are often the first to be approached for financing, for guarantees, and for advice in structuring a PPP. Second, MDBs are repositories of technical expertise and the specialized human capital needed for the development of highly idiosyncratic and complex infrastructure projects. Third, as multilateral agencies, with strong professional cultures and international governance structures, they are ideally placed to enforce credible anti-corruption standards in the selection and enforcement of PPPs. And this all the more so, when their continuous, long-term, unavoidable presence on the ground, puts them in a position to withhold future projects from governments and private operators that have been found to engage in corruption. In short, MDBs play a critical gate-keeping and technical assistance role in infrastructure investment.

MDBs also provide much of the financing for the infrastructure projects they originate. But public funding capacity and the size of MDB balance sheets more than ever fall woefully short of the global demand for infrastructure investment. This is why the new model for MDBs is an origination-and-distribution model, where MDBs help structure new PPP deals that will be increasingly financed by the large pool of global savings seeking higher yielding long-term investments than government bonds.

\subsection{MDBs: From funders of public sector projects to originators and distributors of PPPs}

Traditionally, the role of public development banks, and later that of MDBs, has been seen as a public response to a failure by private banks and securities markets to finance valuable, large-scale, long-term, (infrastructure) investments. With the backing of the State, development banks could afford to make longer term commitments than private banks, and through their long-term infrastructure investments could serve as catalysts to coordinate the financing of industrialization by private banks (Diamond, 1957, Gerschenkron, 1962, Armendáriz de Aghion, 1996, and Da Rin and Hellman, 2002). The model of development banks in $19^{\text {th }}$ century Europe was based on the idea that they could be profitable if they sufficiently internalized the positive spillovers from industrialization, a form of value capture.

The model of MDBs post WW2 was further seen as palliating the underdevelopment of banking and financial markets in developing countries post decolonization (Levy-Yeyati, Micco and Panizza, 2004, and de LunaMartínez and Vicente, 2012). In the early years of economic development post decolonization, the role of the state in coordinating investment was paramount. Accordingly, most of the early investments of MDBs went to funding public sector projects. But as the central role of the state in the economy was reassessed and more and more developing economies have transitioned away from large public sectors towards more market-based models the mandate of MDBs also evolved. ${ }^{12}$ Yet, MDBs remain fundamentally different from ordinary commercial banks in several respects. First, the mandate of MDBs is to stay away from commercially viable investments to avoid inefficient crowding out of private lenders. Second, the criteria MDBs apply for

\footnotetext{
${ }^{12}$ The European Bank for Reconstruction and Development and the International Finance Corporation, in particular, have reoriented their loans mostly to the private sector.
} 
investment involve the important assessment of the social and economic development impact of the project. Third, MDB debt is senior to other commercial creditors according to existing conventions.

With the shift towards privatization of infrastructure, MDBs increasingly participated as co-investors along with other private sector investors, but the full potential of the new role for MDBs as co-investors has only recently become fully apparent. The exceptional track record of profitable co-investments of the EBRD in the former Eastern Bloc countries under two decades of economic transition, and, most importantly, the spectacular growth impact of another development bank over the last decade and a half-the China Development Bank (CDB) - have revealed how far a development bank model built around a modernized value capture concept and a co-investment formula with private lenders can accelerate economic development while generating more than adequate financial returns (see Box B). As can be seen in Figure 2, by 2015 CDB assembled a balance sheet with assets exceeding $\$ 1.8$ trillion, which is more than the sum of all assets on the balance sheets of all MDBs combined in 2015 (World Bank, EBRD, ADB, IADM, African Development Bank and EIB). CDB was founded in 1994 and built its balance sheet in record time, mostly in the last decade, as it had total assets in 2004 were only \$205 billion according to its annual report. Admittedly, CDB benefited from a unique environment in China and a privileged position in China's financial system. But the development formula it perfected can be adapted and is replicable elsewhere.

To fully play their role as originators and distributors of infrastructure projects, however, MDBs must venture further in the direction of playing more of an investment banking role, coordinating deals between government agencies, private concession operators, and long-term private investors, offering when necessary guarantees and credit enhancements that protect private investors from risks they are not prepared to carry. In addition, MDBs must further explore the bundling of multiple PPP projects towards infrastructure asset-backed securitization to be able to reach sufficient scale in bond financing to attract institutional investors. Indeed, most PPPs are too small in scale for large long-term institutional investors, such as pension funds, reserve funds, and sovereign wealth funds, who do not always have dedicated infrastructure experts in their management teams. 


\section{Box B. China Development Bank Model of Investment}

The investment model perfected by CDB arose out of a unique Chinese local economic development context. Strapped for funding and with a highly restricted tax base, Chinese municipalities increasingly relied on capital gains realized from urban development to fund themselves. An early notorious example of such successful urban development, financed by CDB, is known as the Wuhu model (see Sanderson and Forsythe, 2013).

Under this model a municipality would set up a special purpose vehicle charged with developing a designated zone. This entity could borrow from CDB as a senior long-term lender as well as from other commercial banks on a subordinated basis to finance the infrastructure and real estate towards urban development of the dedicated zone. Crucially, as development proceeded and land values appreciated the special purpose vehicle could sell land and development rights to real estate developers and thus realize the capital gains that would serve to repay the loans of CDB and the other commercial banks and fund municipal expenditures. Equally important is the arrangement that CDB strikes with the special purpose vehicle, collateralizing its loans with the proceeds from future land sales. In other words, the CDB lending model is built on an urban development formula that enables value capture through land and developmentright sales akin to the value capture that Hong Kong's MTR relied on to finance the expansion and operation of its mass transit network, although CDB also successfully invested in many other areas and other infrastructure projects beyond mass transit networks.

To fund its investments, CDB also benefits from a unique position similar to that of the governmentsponsored enterprises (GSEs) Fannie Mae, Sallie Mae, and Freddie Mac in the US. Just as the GSEs, CDB can finance itself by issuing long-term bonds that financial markets perceive as indistinguishable from straight government bonds once CDB has secured the endorsement of the Ministry of Finance. As these bonds typically offer yields that are slightly higher than interbank rates, and significantly higher than the rate paid on excess reserve accounts by the central bank, they are very attractive to commercial banks with excess liquidity holdings. A key advantage of this funding structure is that CDB could build a massive balance sheet with a lean organization —although its balance sheet is six times larger than that of the World Bank it has only 3,500 employees as of 2015.

Although CDB like the GSEs was ideally placed to exploit some unique structural advantages, it also built a sustainable lending model for a development bank by implementing strict and sophisticated protocol for approval of new projects, so much so that it stands out relative to commercial banks in terms of its low fraction of non-performing loans (see again Sanderson and Forsythe, 2013). That is obviously not a given for a development bank, yet it is an essential condition for the success of any MDB. Much of the credit for implementing this rigorous lending protocol goes to the founding chairman of CDB, Chen Yuan. 


\subsection{Infrastructure platforms}

Based on the more recent experience of some MDBs with co-investments with private investors, there is growing appreciation globally that MDBs can indeed play a much bigger role in the preparation, structuring, and financing of infrastructure projects along with private long-term investors. Not coincidentally, a number of infrastructure platform initiatives have been launched very recently by several MDBs, most of them still at a prototype development stage, with the aim of scaling up the distribution of investments in PPP projects to private investors and thereby increase the flow of origination of new infrastructure facilities.

In the following, we discuss four different models that are currently at various stages of development. These platforms are all different attempts to tap into the vast pool of global long-term savings by better meeting long-term investor needs and attract them to infrastructure assets by relaxing operating and governance constraints traditional development banks have been facing. One specific example of constraints that development banks have been subject to is their governance structure centered exclusively around governmental actors, which de facto make it impossible for private investors to be actively involved in the orientation given to infrastructure investments both on the origination and financing fronts. We begin with a brief description of these four platforms, which will help give context to the subsequent critical assessment of the existing trade-offs and potential limitations of the models currently being proposed ${ }^{13}$.

\subsubsection{The European Investment Bank model}

With subscribed capital of over 240 billion Euros, total assets just exceeding $\$ 600$ billion in 2015, and funded projects in over 160 countries, the European Investment Bank (EIB) is currently the world's largest multilateral investment bank ${ }^{14}$. The EIB has been set up by the European Union with a very conservative business model under which the EIB is only allowed to borrow 2.5 times its subscribed capital. This ensures that it can always issue AAA-rated bonds. Not all of EIB investment is in infrastructure. The EIB also plays a major role in the funding of innovation, climate change mitigation, and small and medium enterprise (SME) loans.

The EIB's most innovative infrastructure investment activities are in project finance. This is where the EIB provides an interesting new infrastructure platform model for development banks that can support PPP infrastructure projects. The EIB's involvement can reinforce PPP projects at several levels, whether it is in project preparation, as a co-investor, a lender, or a servicer. A typical PPP in which the EIB is involved will have about 70 percent of the investment funded initially either through a bank loan, that may subsequently be refinanced in the bond market, or through a long-term project bond, with the EIB providing support either through a credit enhancement scheme to remove exposure of creditors to construction and early operating

\footnotetext{
${ }^{13}$ There are several other important global infrastructure investment initiatives that are at various early stages of development. They include: the Junker Plan, November 2014, the G20 Global Infrastructure Initiative, November, 2014, the establishment by the European Commission of infrastructure investments as a new asset class, October 2015, and the launch by the International Finance Corporation (IFC) of a new accounting platform earmarked for infrastructure projects in emerging markets, November, 2015 (see Winrow, 2015).

${ }^{14}$ The China Development Bank is not a multilateral institution.
} 
risks (a line of credit, a subordinated debt tranche), or through an equity co-investment with a private longterm infrastructure investor such as Meridiam or DIF among others. ${ }^{15}$

Participation by the EIB in a project has two main advantages. A first obvious benefit is that the EIB offers more loss absorbency protection to private investors who buy the project bond. As a result, these investors are prepared to both extend the maturity of the bonds and lower their required rate of return, thus reducing the overall cost of capital of the project. ${ }^{16}$ The second related benefit is that when the EIB is involved as an investor and in the servicing of the PPP debt, the government partner in the PPP is more likely to honor the terms of the concession contract. The reason is that the EIB is a key long-term agent in the infrastructure investment space, with essential expertise in project preparation and servicing, with whom the government entity will be expecting to have to interact with multiple times on future projects. This entity will therefore think twice before reneging on contractual promises or before deciding to hold up the PPP operator. A third important benefit is that when the EIB is involved, even with a relatively small stake in the form of a project bond credit enhancement, it will apply its due diligence expertise and rigorous standards for investment, thus further reducing the credit risk for project bond investors.

Another interesting recent EIB securitization initiative is the creation of a renewable energy platform for institutional investors (REPIN) that offers repackaged renewable energy assets in standardized, liquid forms to institutional investors ${ }^{17}$. Although interest from institutional investors in this initiative has been limited so far, the new carbon footprint disclosures and regulations of institutional investors that are expected be implemented after the Paris COP 21 climate agreement, could nudge more pension and sovereign wealth funds to take on these securities.

\subsubsection{The World Bank's Global Infrastructure Facility (GIF)}

The World Bank Group launched a major new initiative with the GIF, officially established at its October 2014 Annual Meeting. The World Bank's involvement in infrastructure investment is of course not new. It has been engaged in infrastructure financing ever since its creation in 1945, and has thus accumulated a deep expertise in this area. In recent years the World Bank has progressively recognized that there is a new reality for global infrastructure investment and that there are untapped funding opportunities from private investors, which could help the World Bank respond to the huge demand it receives from member countries. This is why it has launched this major new initiative. The World Bank has two important objectives for the GIF. First, make better use of its exceptional talent pool to accelerate origination of new projects, and second relax its current tight funding constraints driven by its limited capital base, which no-one expects will be increased substantially in the near future, by co-investing more with private investors. As prompted by the G20, the World Bank hopes to leverage its global infrastructure expertise by bringing in private funding from longterm investors through the GIF facility set up specially to co-invest along with private investors. Originally, the GIF has been set up as an entity outside the World Bank with a total capital of $\$ 200$ million. That capital was destined to be leveraged with A+ rated debt held by private investors so as to finance potentially much larger projects.

\footnotetext{
${ }^{15}$ For information on DIF, see http://www.dif.eu/

${ }^{16}$ Without proper monitoring, loss absorbency could lead to over-provisioning and under monitoring.

${ }^{17}$ See http://climatefinancelab.org/idea/renewable-energy-platform-for-institutional-investors-repin/
} 
The initial contours of the GIF, however, appeared uncertain to the World Bank membership. Two main issues, in particular, have arisen. First, there the concern that building a sound "infrastructure balance sheet" could take a long time. Second, the participation of new actors would have implied a change in the governance structure which appeared unlikely at the time. In that context, the current design of the GIF with a more limited scope was deemed more realistic. One of the important unresolved logistical issues is when to bring in private investors: at an early project preparation stage or much later as a residual investor when all the parameters of the project have been set. Issues regarding oversight of social and environmental protection in large-scale infrastructure projects in developing countries by the World Bank's GIF have also been raised, particularly with respect to some fossil fuel investments in Africa and a coal mining project in Kosovo, expected to displace approximately 7000 people (Bretton Woods Project, 2014).

Currently, the GIF platform is designed to help identify, prepare, and also supervise projects. In addition, since there are issues also on a project by project basis in every country, which requires policy amendments or policy interventions, and considering that the World Bank Group is present all over the world, it is better positioned to enhance the overall policy framework. Building on the World Bank's expertise in infrastructure financing, the GIF offers services in terms of identifying and preparing projects. The GIF will start with a few pilot projects amounting to up to $\$ 2$ billion. A total of $\$ 80$ million is being budgeted for preparation of those projects. And on the downstream side, GIF is budgeting $\$ 200$ million. The modalities on how to integrate the upstream and downstream sides are yet to be decided upon.

\subsubsection{The European Bank for Reconstruction and Development (EBRD) Equity Participation Fund}

The EBRD fund envisions that private long-term investors be admitted as equity co-investors to the new Equity Participation Fund it set up. A fixed allocation ratio will be followed for eligible investments in equity with $30 \%$ of investment risk allocated to the fund. The EBRD retains $70 \%$ of the investment risk and private investors in the fund are passive and follow the EBRD investment protocol.

The target size of the fund is between EUR 750 million and 1 billion. The expected investment size is between EUR 10 to 100 million. The expected portfolio return is a 15\% internal return rate. The fund term is 12 years. Hence, one of the biggest limitations to EBRD's Equity Participant Fund is that the time horizon for return on investments in infrastructure is far too short, bearing closer resemblance to private equity investment patterns than to long-term investors in global infrastructure, with a minimum period of 25-30 year time horizons. In North Africa, for example, the EBRD's Equity Participation Fund is the largest limited partner in infrastructure initiatives, by serving as co-investor in more than 170 private equity funds. To date, the EBRD has made $€ 10$ billion cumulative equity investments in infrastructure across 36 countries.

The main advantage of the fund is to provide an opportunity to invest in the growth potential across the EBRD countries of operation, which are not accessible via public markets or traditional private equity funds. Indeed, global institutional investors who participate in the EBRD's direct equity investment portfolio and strategy will benefit from geographic and sector diversification, as well as the long-term capital growth and return opportunity in line with market benchmarks. In addition, fund investors also benefit from the EBRD adherence to the highest environment, social and governance (ESG) standards and unique access to a universe of both public (pre-privatisation) and private companies. In terms of risk mitigation, the EBRD has stringent internal processes as well as very low-cost intermediation (cost sharing management fee, no carried interest). 


\subsubsection{The Asia Infrastructure Investment Bank}

The latest multilateral development bank to be created is the Asia Infrastructure Investment Bank (AIIB) expected to start operations this year. Unlike other development banks it is entirely dedicated to infrastructure investment, as its name indicates. It has a start-up committed capital of $\$ 50$ billion with another $\$ 50$ billion in future capital commitments. While the total committed capital of the AIIB is lower than the EIB's, its maximum leverage ratio is much higher (borrowing may be as high as 20 times capital) so that total assets of the AIIB could be double those of the EIB when it reaches full capacity.

The launch of the AIIB has been held back by US opposition to Asian countries joining the AIIB. However, the recent announcement that the UK, France, Germany and Italy are joining the AIIB has been a turning point. The AIIB now has more than thirty member countries, including India and Indonesia, with each member's voting rights on the governing board benchmarked to be proportional to the member country's share of GDP.

The creation of the AIIB is a significant step towards meeting the $\$ 8$ trillion of Asian infrastructure investment needs over the next decade estimated by the Asia Development Bank (ADB). That being said, it is highly unlikely that the AIIB will be crowding out investment efforts by existing multilateral development banks, given that these institutions do not have the balance sheets to be able to meet these enormous infrastructure investment needs. The ADB has a committed capital base of about $\$ 160$ billion and the World Bank about $\$ 220$ billion, but much of that capital is already deployed in existing projects and their mandates are much broader than infrastructure. A multilateral development bank entirely dedicated to infrastructure and with significantly larger potential leverage than existing development banks is much closer to the future infrastructure platform model that can unlock the bottleneck preventing the flow of long-term savings towards long-term infrastructure assets. With a higher projected leverage it is likely that the AIIB will not just be issuing AAA rated bonds to long-term investors, but also lower rated bonds with a higher yield, which should make these particularly attractive to long-term investors in the current global low yield environment. Another advantage of a large development bank, fully dedicated to infrastructure, is that it can fund much larger projects and coordinate investment for entire infrastructure networks, thus increasing the profitability of individual projects. This is particularly relevant for transport, water, and electricity infrastructure projects.

\subsection{Tradeoffs and Next Challenges}

Several lessons can be drawn from this brief description of the four infrastructure investment platforms. A first obvious lesson is that the ability of development banks to leverage public money -committed capital from government contributions-by attracting private investors as co-investors in infrastructure projects is increasing the efficiency of development banks around the world. It is not just the fact that development banks are able to invest in larger-scale infrastructure projects and thus obtain a greater bang for the public buck, but also that these private investors together with development banks can achieve more efficient PPP concession contracts. Development banks are not just lead investors providing some loss absorbing capital to private investors. They also give access to their expertise and unique human capital to private investors, who would otherwise not have the capabilities to do the highly technical, time-consuming, due diligence to identify and prepare infrastructure projects. In addition, they offer a valuable taming influence on opportunistic government administrations that might be tempted to hold up a private PPP concession operator. Private investors in turn keep development banks in check and ensure that infrastructure projects are economically 
sound and not principally politically motivated. No wonder that this platform model is increasingly being embraced by development banks around the world.

At the same time these platforms look more like green shoots next to the enormous global challenge of originating an aggregate flow of infrastructure projects of the order of one trillion dollars per year for the next two decades. As promising a model for future PPP infrastructure concessions they can offer, this model needs to be scalable to deliver on the promise of channeling under-used, long-term, savings towards more sustainable investments. To achieve greater scale a number of aspects of the infrastructure platform model could be further refined and other avenues for infrastructure platforms should be pursued.

A first area that merits rethinking is the process of project preparation and the protocols for allocating human capital resources inside development banks to specific infrastructure projects. A related issue is how development banks can ensure that reliance on human capital resources is adequately compensated, given that only a fraction of the projects that are being considered will turn out to be 'bankable' and worth bringing to completion ${ }^{18}$. The current model is essentially one where a host government approaches a development bank to initiate the investigation and preparation of an infrastructure project. It is only after a first round of screening that the development bank undertakes more thorough due diligence and project preparation. Private investors are brought into the picture fairly late in this process, if at all. They are often the last parties to be brought into the picture, at a point when the main contours of the project are already set. Institutional investors have become so accustomed to being spoon-fed nearly completed deals that they currently show little interest in getting involved in earlier stages. However, if the deal flow is to be significantly ramped up the current model has to be revamped to incentivize institutional investors to work with development banks at earlier stages of the preparation of bankable projects.

There are a number of potential obstacles created by this process. First, if there are no clear rules for allocating the right infrastructure experts to new projects, as they come along, there could be substantial inefficiencies and unnecessary bureaucracy involved in the project preparation phase. Not all development banks are yet fully set up to fulfill their role in providing expertise optimally to the right projects. Ideally development banks should have an internal labor market for infrastructure experts with sufficiently widely available information on who is expert on what and who is available to work on a new project. There should be a form of bidding process in place so that experts get matched to the right projects and are adequately incentivized to work on the right projects. Equally, there should be a shadow price for this expertise that is included in the overall cost of infrastructure projects. One difficult pricing problem is how to charge for this expertise on projects that are not undertaken. If the cost of project preparation and due diligence is only imputed on those projects that end up being developed then there will be a number of distortions. Development banks could end up being flooded by requests; too many to be able to handle. And they may have to devote a significant fraction of their income to pay their experts. This, in turn, could give rise to understaffing and the creation of too small infrastructure teams. Development banks could, of course, relax this staffing constraint by outsourcing project preparation to outside consultants, but without the long-term commitment of institutional investors to participate in the

\footnotetext{
18 According to the EIB a PPP project is considered to be bankable if "lenders are willing to finance it. The majority of PPPs are funded on a project finance basis where a special purpose vehicle is established to ring fence the project revenues and debt liabilities.”

http://www.eib.org/epec/g2g/i-project-identification/12/123/index.htm
} 
origination of new projects and, possibly, in sharing project preparation costs, development banks will not have sufficient financial resources to bring in such outside consultants.

But possibly the most important shortcoming with the current process of project preparation is that private investors are largely thought of as passive players, with perhaps the exception of the handful of private infrastructure investment funds that actively cooperate with development banks in the preparation of projects they co-invest in as long-term equity investors. But, if the infrastructure platforms are to be scaled to an adequate size then the overwhelming source of private capital will come from long-term asset managers such as pension funds, insurance companies and sovereign wealth funds. These investors are currently mostly thought of as passive players that will only be approached when the project preparation work has been completed and additional sources of funding are sought.

However, the largest private investors, who after all could hold a large bundle of infrastructure assets, should be brought in much earlier and be allowed to play a much more active role. These investors will have a more global view of which infrastructure projects are bankable than the development banks that are currently geographically restricted. They should also be able to initiate or propose projects to be studied and prepared. Global institutional investors could have a better sense of what a whole infrastructure network should look like - a network of waterways, canals, sewage systems, electric grids, roads, railways, etc.- to make each individual project in the network bankable ${ }^{19}$. This is all the more likely if the efficient growth of the network is transnational and involves coordination of neighboring host governments, who are not necessarily used to cooperate with each other on infrastructure development. In sum, an infrastructure project initiative could also come from investors, with development banks providing investors access to host governments and playing the role of project preparation facilitators.

Furthermore, another important role of development banks in supporting infrastructure investment platforms is to undertake more comprehensive planning of infrastructure investments and how each individual project may fit into a broader infrastructure network development plan. An obvious risk in considering each project on an ad-hoc and isolated basis is that the project is more likely to be assessed as non-bankable. Building and operating a new highway may be seen as generating too few immediate development benefits and toll revenues if the subsequent development of an entire road system and other infrastructure projects is not taken into account. The same is true for investments in electrification, water, railways, and other transport networks. To the extent possible infrastructure investments should also be structured to allow the developer and operator to capture the external value created by the investment. As the Hong Kong MTR example strikingly illustrates, value capture especially for urban infrastructures is an effective way of ensuring the bankability of infrastructure investments.

Finally, the EBRD experience illustrates that many of the investments currently made by development banks are either not in infrastructure at all or not sufficiently in greenfield infrastructure projects. The reason is that a ten or twelve year payback horizon for a project is just too short. A recent example that illustrates the risk of development banks creeping away from greenfield and more into brownfield is the EBRD's investment in the modernization of railways in Moldova in November 2014. The investment no doubt enhances the efficiency of the railway and its revenue generating capacity. It is also an important contribution to the economic development of Moldova. Nevertheless, this is not a true greenfield investment in a new railway, which the EBRD is not set up to do given its somewhat short investment horizon.

${ }^{19}$ So far, most PPP projects have been envisioned at a national level, even in the EU. The coordination of PPP projects at a transnational level is complex and involves significantly longer preparation, which makes them less attractive to private sector investors. 


\section{CONCLUSION}

This paper is a first attempt to conceptualize and put into perspective the dramatic evolution of the global architecture of infrastructure finance, which so far has only received the attention of development finance policy circles, and not been the subject of academic study. The infrastructure platforms we discussed will certainly help on two important fronts, namely the financing and origination of infrastructure projects. Obviously our paper is only a first introduction to the institutional design of infrastructure platforms and much more systematic and formal research is needed to identify the optimal contract features of infrastructure platforms and multilateral PPPs.

On the more immediate economic policy front, our paper is a call for governments and MDBs to ramp up the early prototypes of infrastructure platforms, and improve the technical capabilities of host governments to be able to better cooperate with MDBs in the preparation and financing of new PPPs, so that the flow of origination of infrastructure assets reaches a critical mass large enough to be a material alternative for most large, long-term, institutional investors. Two important sets of policies are needed to further this agenda. First, the promotion of standardization of underlying infrastructure projects is essential to help scale up investment into infrastructure-based assets. Large physical infrastructure projects are indeed complex and can differ widely from one country to the next. In that respect, governments and MDBs should help provide the institutional environment to encourage the use of securitization techniques such as collateralized bond obligations (or CBOs) or collateralized loan obligations (or CLOs), which will enhance the efficiency of the market and allow for a more effective pooling of risk. Securitization would also be a way of increasing the size of infrastructure-backed bond offerings and thereby attract the interest of larger long-term investors. Overall, securitization can provide many advantages such as diversification for investors, lower cost of capital by allowing senior tranches to be issued with higher credit ratings, as well as higher liquidity. At the same time, securitization also creates debt instruments of variable credit risks to match the different risk appetites of investors. Second, governments and MDBs should promote the important complementarities between actors participating in the "value chain" created by platforms that include host countries, financial investors, guarantors and financial intermediaries.

Finally, many host countries have viable long term infrastructure projects waiting to be developed, but without the provision of guarantees to address construction, demand, exchange rate risks, these projects currently will not be funded. A basic economic principle is that risks should be assumed by those best placed to hold them. Governments are the natural holders of political, regulatory and governance risks. The private sector developers and operators of the infrastructure facilities for obvious incentive reasons should take on most of the construction risk, but demand risk should probably be shared, depending on the sector and type of project. Accordingly, an important complement to the development of infrastructure platforms around MDBs is the creation of multilateral guarantee funds that can take on political, regulatory and exchange rate risk, and thus make infrastructure investments more attractive to private long-term investors. 


\section{REFERENCES}

Allianz, 2015. The illiquidity advantage of Infrastructure Debt, May.

Armendáriz de Aghion, B. 1999. “Development Banking” Journal of Development Economics 58: 83-100.

Bennett, John and Elisabetta Iossa, 2006. "Delegation of Contracting in the Private Provision of Public Services," Review of Industrial Organization, Springer, vol. 29(1), pages 75-92, September.

Blackrock, 2015. “Infrastructure Rising: An Asset Class Takes Shape” April.

Bretton Woods Project: Critical Voices on the World Bank and the IMF, "Risking the bottom line: World Bank Infrastructure Initiatives Criticized”, 29 September 2014. http://www.brettonwoodsproject.org/2014/09/riskingbottom-line-world-bank-infrastructure-initiatives-criticised/

Cervero, R. and J. Murakami (2009), "Rail + Property Development in Hong Kong: Experiences and Extensions,” Urban Studies, Vol. 46, No. 10, pp. 2019-2043, 2009.

Çelik, S. and M. Isaksson (2013), “Institutional Investors as Owners: Who Are They and What Do They Do?”, OECD Corporate Governance Working Papers, No. 11, OECD.

City UK, The (2013), Sovereign Wealth Funds report, March 2013.

Da Rin, Marco and Thomas Hellman (2002), “Banks as Catalysts for Industrialization,” Journal of Financial Intermediation, 11:366-397.

de Luna-Martínez, José and Carlos Leonardo Vicente (2012), “Global Survey of Development Banks”, World Bank Policy Research Working Paper No. 5969

Donaldson Dave (2016) "Railroads of the Raj: Estimating the Impact of Transportation Infrastructure," American Economic Review, forthcoming.

Donaldson Dave, and Richard Hornbeck, (2016). "Railroads and American Economic Growth: a "Market Access" Approach”. Quarterly Journal of Economics, forthcoming.

Donahue, John D. 1989. The Privatization Decision: Public Ends, Private Means. New York, Basic Books.

Dewatripont, Mathias and Legros, Patrick, 2005. "Public-private partnerships: contract design and risk transfer", EIB Papers 5/2005, European Investment Bank, Economics Department.

Diamond, William 1957. Development Banks. Baltimore: The Johns Hopkins Press

Estache, Antonio and Fay, Marianne, 2007. “Current debates on infrastructure policy,” Policy Research Working Paper Series 4410, The World Bank.

Gerschenkron, A. (1962). “Economic Backwardness in Historical Perspective,” Harvard University Press, Cambridge.

Hammami, Mona and Ruhashyankiko, Jean-François and Yehoue, Etienne B., 2006 "Determinants of Public-Private Partnerships in Infrastructure”, IMF Working Paper 06-99: pp. 1-39.

Hart, Oliver. 2003. "Incomplete Contracts and Public Ownership: Remarks, and an Application to Public-Private Partnerships,” Economic Journal vol. 113(486): C69-C76, March.

Holmstrom, Bengt. 1979. “Moral Hazard and Observability,” Bell Journal of Economics, vol. 10(1), pages 74-91, Spring.

Holmstrom, Bengt and Jean Tirole, 1998. "Private and Public Supply of Liquidity,” Journal of Political Economy vol. 106(1), pages $1-40$.

Iossa, Elisabetta and David Martimort, 2012. "Risk allocation and the costs and benefits of public--private partnerships,” RAND Journal of Economics vol. 43(3), pages 442-474, 09.

Martimort, David, Flavio Menezes, Myrna Wooders and Elisabetta Iossa, 2015. “The Simple Microeconomics of PublicPrivate Partnerships,” Journal of Public Economic Theory vol. 17(1), pages 4-48, 02.

Engel, Eduardo, Fischer, Ronald, Galetovic, Alexander, 2008. “The Basic Public Finance of Public-Private Partnerships,” Working Papers 35, Yale University, Department of Economics.

European Commission, 2011. Project Bond Initiative. Commission Staff Working Paper, February.

European Commission, 2013. Long-Term Financing of the European Economy. Green Paper, March.

Fernald, John G., 1999. "Roads to Prosperity? Assessing the Link between Public Capital and Productivity,” American Economic Review, 89(3): 619-638.

Levy Yeyati, Eduardo, Alejandro Micco and Ugo Panizza, 2004. "Should the Government Be in the Banking Business? The Role of State-Owned and Development Banks,” Research Department Publications 4379, Inter-American Development Bank, Research Department.

Lucas, Deborah 2014. "Evaluating the cost of government credit support: the OECD context," Economic Policy, vol. 29(79): 553-597, 07.

LP Perspective, 2014. “Inside the Limited Partner”, December/January.

Martimort, David and Pouyet, Jerome, 2008. “To build or not to build: Normative and positive theories of public-private partnerships,” International Journal of Industrial Organization vol. 26(2): 393-411.

McKinsey Global Institute, 2013. Infrastructure productivity: How to save \$1 trillion a year. http://www.mckinsey.com/insights/engineering_construction/infrastructure_productivity

Mirrlees, J A, 1999. “The Theory of Moral Hazard and Unobservable Behaviour: Part I”, Review of Economic Studies vol. 66(1): 3-21.

Morgan Stanley, 2007. Investing in Infrastructure: A Primer. Infrastructure Series No 2, May.

NITI AAYOG -NITI BRIEF \# 5 (2015). “Investment in Infrastructure: Strengthening PPP Policy framework.” 
Organisation for Economic Co-operation and Development, 2012. Strategic Transport Infrastructure Needs to 2030, March.

Preqin, 2016. “Infrastructure Spotlight”, March Volume 3. Issue 3. Available at: https:/www.preqin.com/

Sanderson, Henry and Michael Forsythe, 2013 China’s Superbank. Singapore. John Wiley \& Sons, Bloomberg Press

Standard \& Poor’s, 2007. "Infrastructure Finance”, April.

Vickers, John, and George Yarrow. 1991. “Economic Perspectives on Privatization.” Journal of Economic Perspectives, 5(2): 111-132.

Winrow, Walter, 2015. “Moody’s Project and Infrastructure Finance Overview,” Keynote address at the NYSSA Third Annual Global Infrastructure Conference.

World Bank, IFC, and World Economic Forum, 2013. Tackling the Infrastructure Finance Deficit, January.

World Bank Group, 2016. Public-Private-Partnerships in Infrastructure Resource Center: Dispute Resolution Systems Available. https://ppp.worldbank.org/public-private-partnership/.../legal.../dispute-resolution

World Economic Forum. (2010). Positive Infrastructure: A Framework for Revitalizing the Global Economy. http://www.weforum.org/pdf/ip/ec/Positive-Infrastructure-Report.pdf

World Economic Forum. (2012). Strategic Infrastructure: Steps to Prioritize and Revitalize Infrastructure Effectively and Efficiently. http://www3.weforum.org/docs/WEF_IU_StrategicInfrastructure_Report_2012.pdf 


\section{APPENDIX}

\section{Figure 1: Global Project Finance Volumes}

\section{US \$billion}

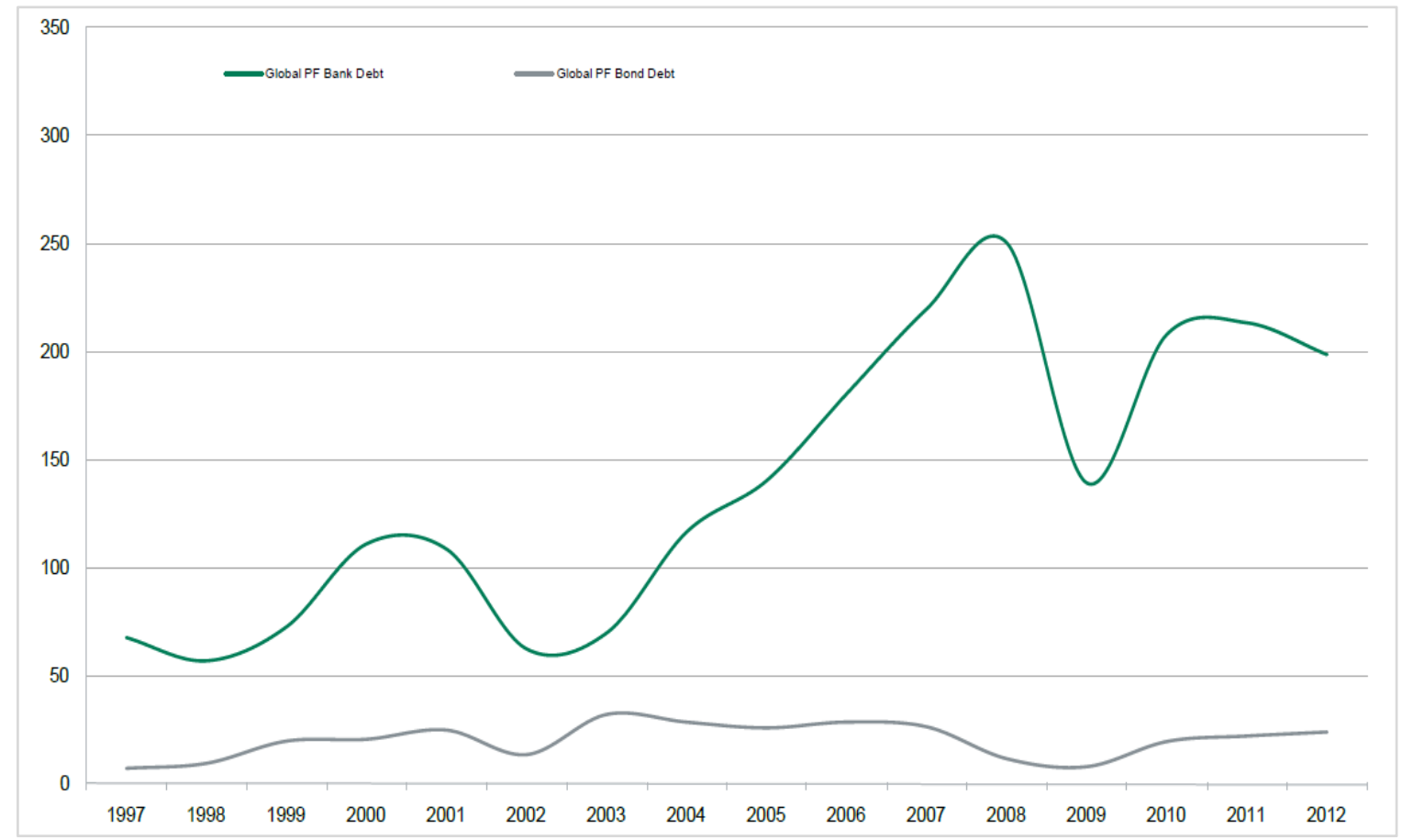

Figure 2: China's National Development Banks in Context Total Asset (US \$billion)

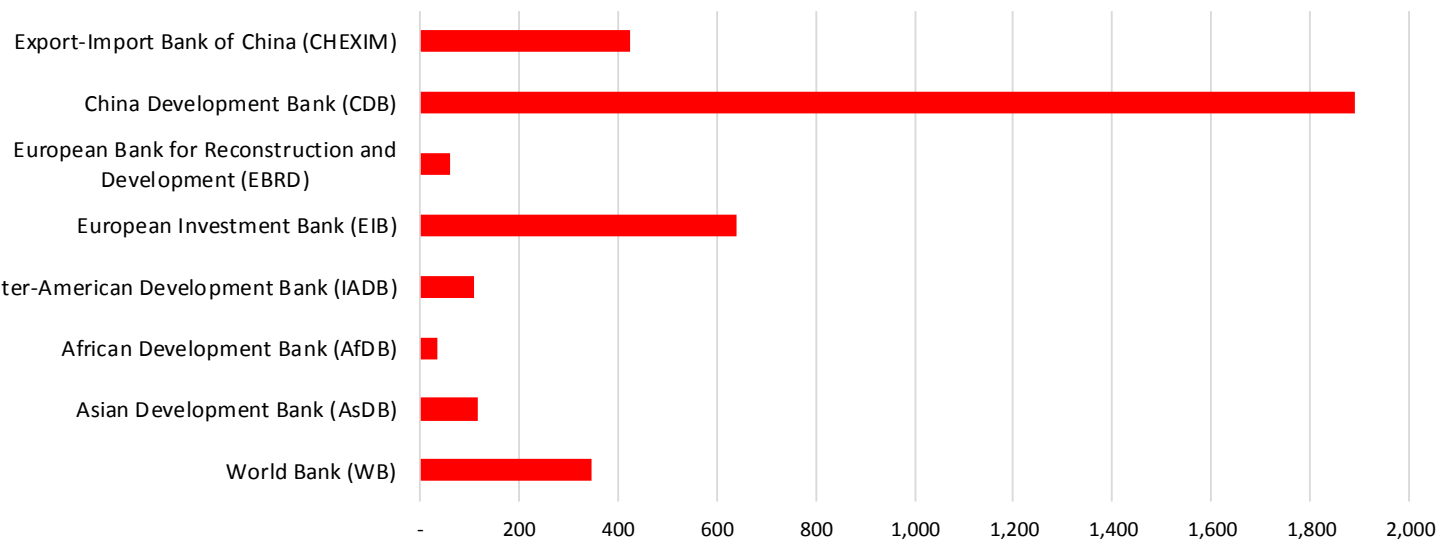

Sources: Bank annual (financial) reports; and IMF staff calculations. Directlinks to the data sources:

China CHEXIM: http://english.eximbank.gov.cn/upload/accessory/20168/201682417629732745.zip;

China CDB: http://www.cdb.com.cn/English/bgxz/ndbg/ndbg2015/201608/P020160831675498298329.zip;

EBRD: http://www.ebrd.com/documents/comms-and-bis/print-financial-report-2015-english-pdf.pdf;

ElB: http://www.eib.org/attachments/gen eral/reports/fr2015en.pdf;

IADB: https://publications.iadb.org/bitstream/handle/11319/7555/Inter-American-Development-Bank-Annual-Report-2015-

Financial-Statements.pdf?sequence $=7$;

AfDB: http://www.afdb.org/fileadmin/uploads/afdb/Documents/Generic-Documents/Annual_Report 2015_EN_-Full.pdf;

AsDB: https://www.adb.org/sites/default/files/institutional-document/182852/adb-financial-report-2015.pdf;

WB: http://siteresources.worldbank.org/EXTABOUTUS/Resources/29707-1280852909811/IBRD_Jun_16.pdf.

Note: 1. All statements are as of December 31, 2015. 2. Total asset of World Bank is represented by total assets of IDRB. 
Figure 3: Global Assets under Management

\$ trillion, end-2012

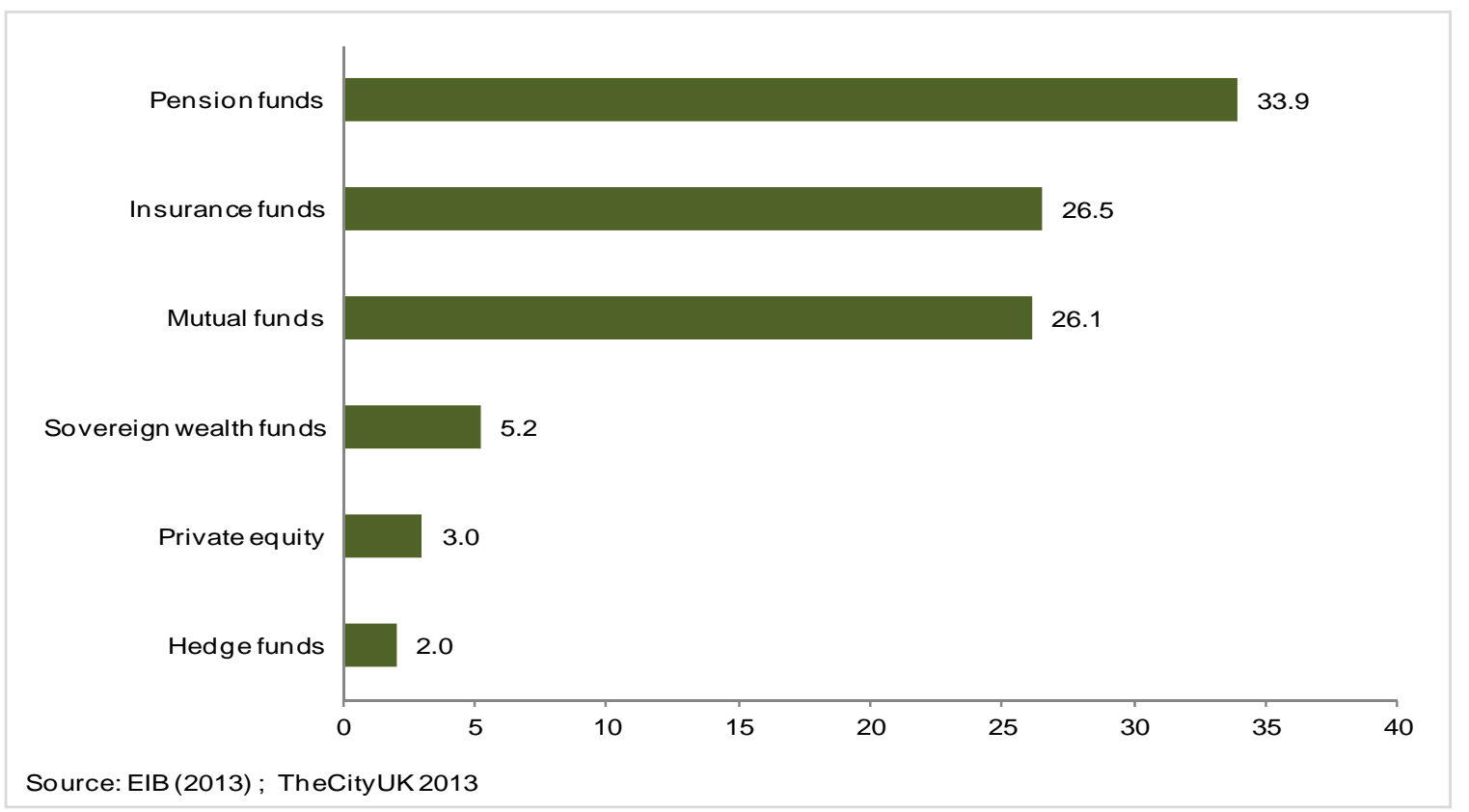

Figure 4: Breakdown of Average Current/Target Allocation to Infrastructures by Investor Type

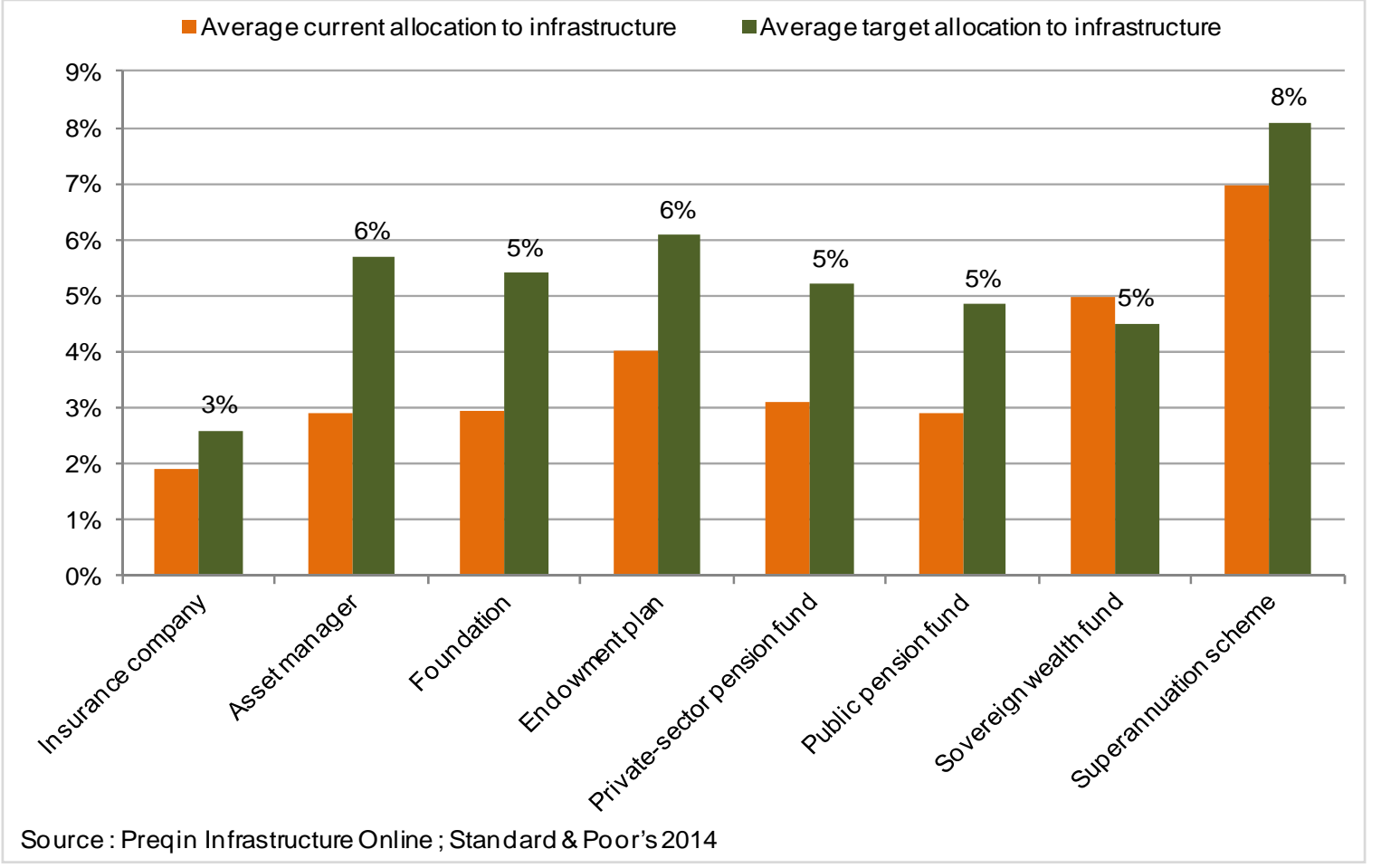


Figure 5: Asset Allocation of Long-term Investors toward Infrastructure Infrastructure allocation (in percent of total)

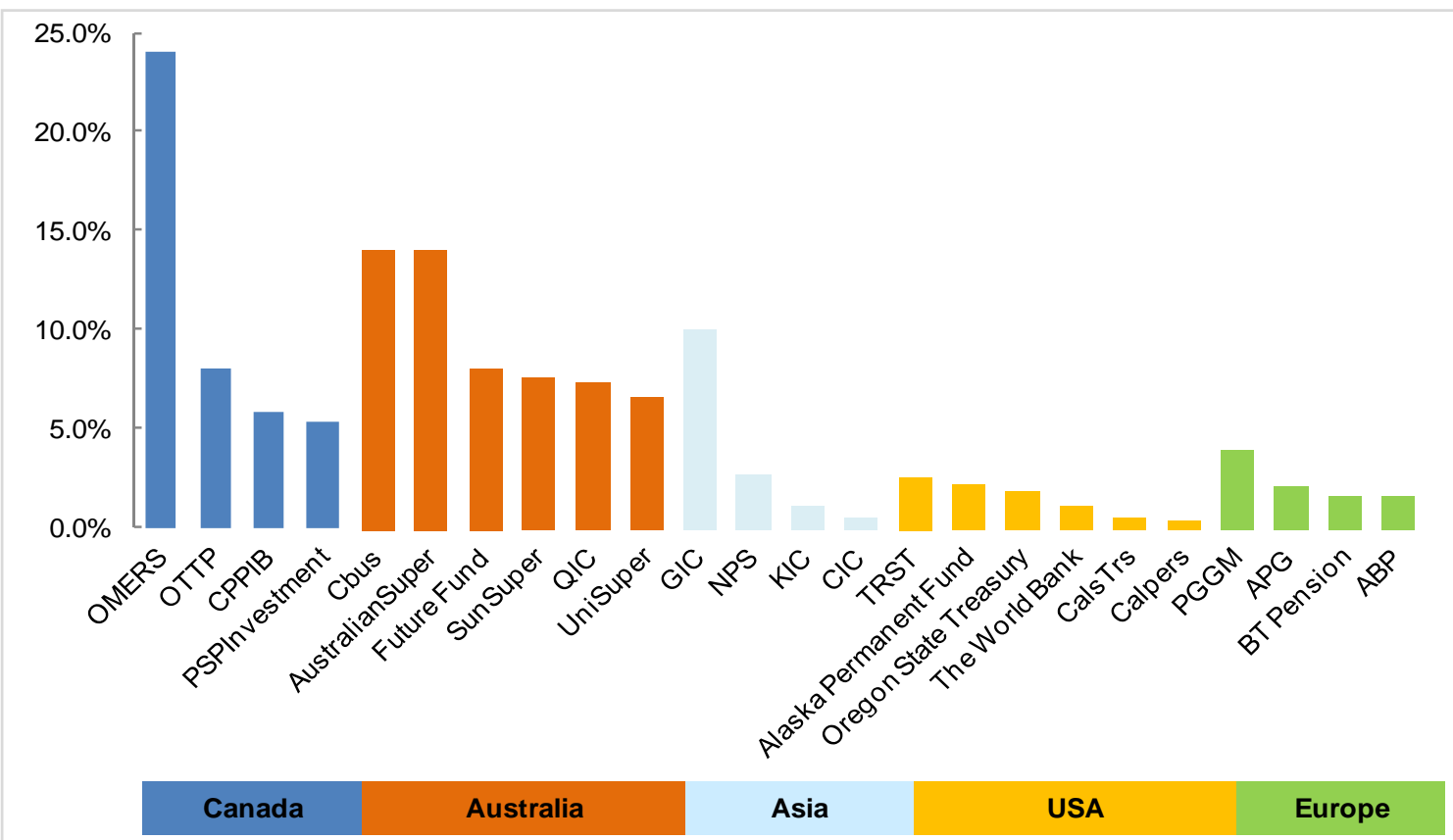

Source : Hermes GPE in Milken Institute Study April 2013 (figure regarding OMERS adjusted by Amundi according to Preqin 2014; Amundianalysis includes QIC, TRST, PGGM, APG) ; Infrastructure Journal

Figure 6: Estimates of Needed Infrastructure Investments, 2013-2030 (\$ trillion, constant 2010 dollars)

\begin{tabular}{|c|c|c|c|c|c|c|c|}
\hline & Roads & Rail & Ports & Airports & Power & Water & -Telecom \\
\hline \multicolumn{8}{|c|}{70 [ } \\
\hline \multicolumn{8}{|l|}{60} \\
\hline \multicolumn{8}{|l|}{50} \\
\hline \multicolumn{8}{|l|}{40} \\
\hline \multicolumn{8}{|l|}{30} \\
\hline \multicolumn{8}{|l|}{20} \\
\hline \multicolumn{8}{|l|}{10} \\
\hline 0 & $\begin{array}{l}\text { Projection } \\
\text { historical } \mathrm{s}\end{array}$ & $\begin{array}{l}\text { ased on } \\
\text { ending }\end{array}$ & $\begin{array}{l}\text { Projec } \\
\text { infras }\end{array}$ & $\begin{array}{l}\text { tion based o } \\
\text { ucture stock }\end{array}$ & $\begin{array}{l}\text { ratio of } P \\
\text { to GDP }\end{array}$ & $\begin{array}{r}\text { rojection b } \\
\text { est }\end{array}$ & $\begin{array}{l}\text { sed on external } \\
\text { nates }\end{array}$ \\
\hline
\end{tabular}


Figure 7: Gap between Infrastructure Supply and Demand

Investment (2010 constant \$trillions)

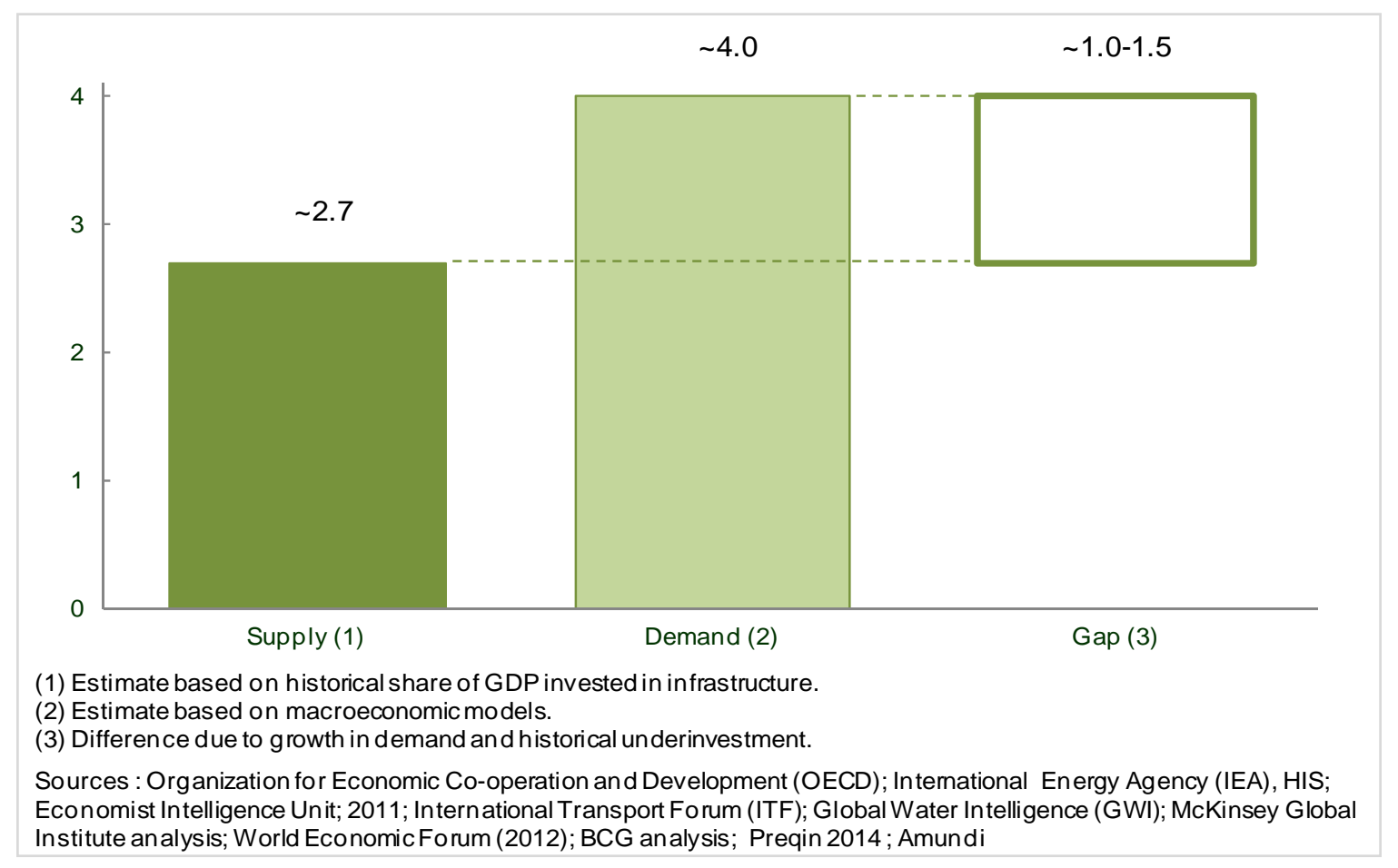

Figure 8: Evolution of the number of Public Private Partnership Projects
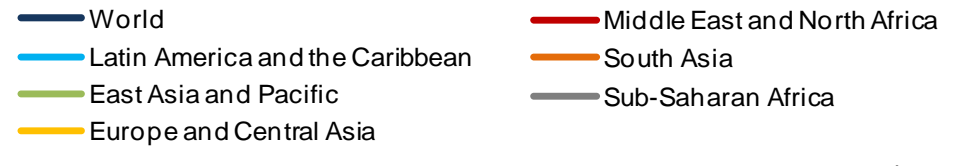

Number of projects
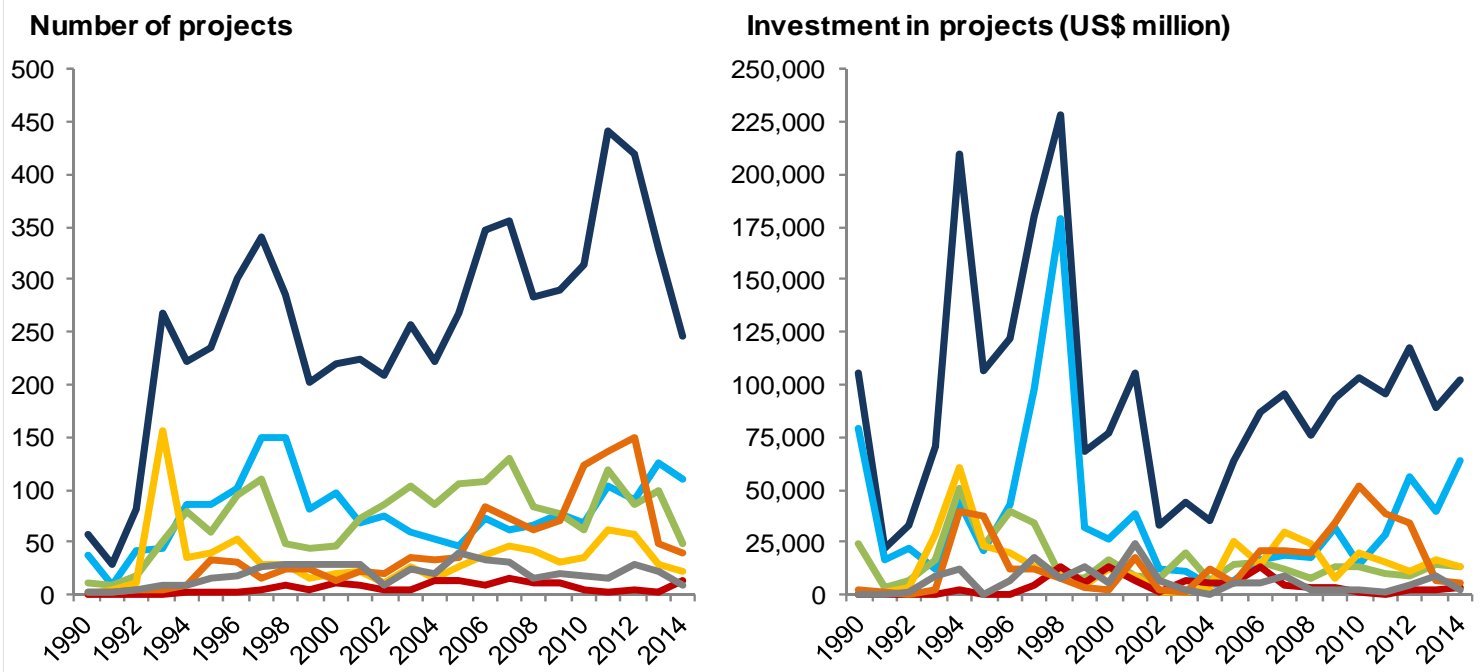

Source: World Bank's Private Participation in Infrastructure database. 
Figure 9: Private Infrastructure Spending in Europe*

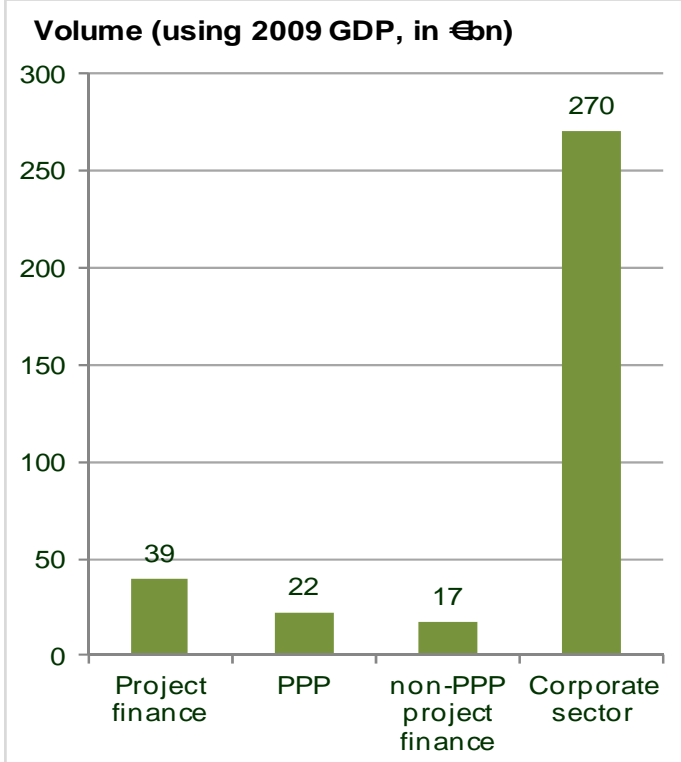

Capital structure of project finance

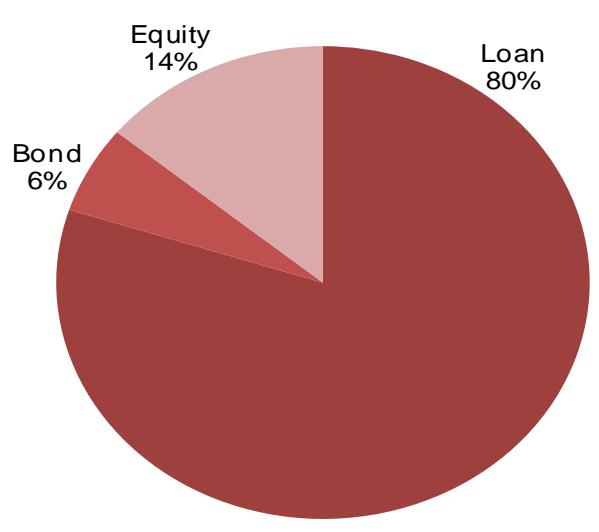

Source: EIB (2013) ; * It is important to note that in th is analysis, private finance is defined as a residual of total infrastructure in vestment (minus government investment (Eurostat figures)), co rporate finance as a residual within private finance (minus project finance (Dealogic figures)), and, finally, non-PPP as a residual within project finance (minus PPP (EPEC figures)).

\section{Figure 10: Risk profile development of an infrastructure asset*}

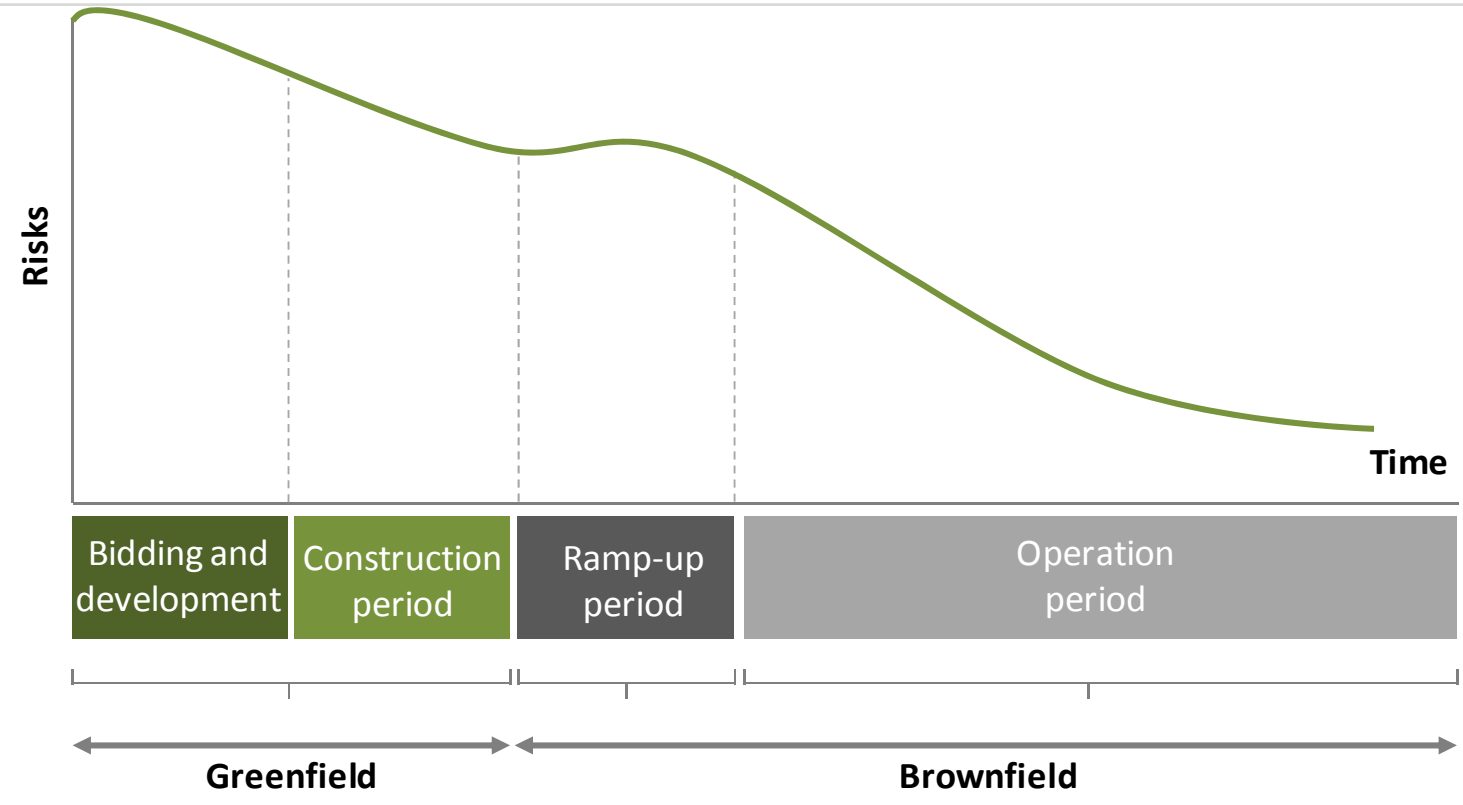

*The figure demonstrates conceptually the relative level of risk between the greenfield and brown field stages of a project, assuming a stable regulatory and political environment. Political and regulatory risks can change the dynamics and lead to a higher relative risk level than shown, especially in the brownfield stage.

Source : World Economic Forum, forillustrative purposes only

Sources : www.citywire.co.uk; Infrastructure Journal; Amundi

* 2013 Global Project Finance, figures from the Infrastructure Journal, a Euromoney Institutional Investor plc service 